\title{
CULTURE, PRODUCT QUALITY AND PRICE EFFECT ON PURCHASE DECISIONS AND THE IMPLICATIONS ON CUSTOMER SATISFACTION (Survey at Golfer Shoe Factory in Cibaduyut, Bandung City)
}

\author{
Ony Djogo ${ }^{1}$, Enung Susilawati ${ }^{2}$ \\ ${ }^{12}$ University Sangga Buana YPKP, Bandung. Indonesia \\ Ionydjogo@gmail.com \\ ${ }^{2}$ nung80@gmail.com
}

\begin{abstract}
Efforts to support product business progress at the Cibaduyut shoe center currently need to be supported by technology, not only in production but also in marketing. Companies can take advantage of technological advancements by marketing products produced online. This system makes it easy for consumers to be used in choosing the desired product according to their needs. Anticipating competition producers among and achieving customer satisfaction, including the need to see good product quality and competitive prices, so that purchasing decisions occured.This study aims to determine the picture of product quality, price, purchasing decisions and customer satisfaction and the effect of the influence of product quality and price on purchasing decisions both simultaneously and partially. The research method used in this research is descriptive verification method with data collection techniques through questionnaires. The results showed that the quality of Golfer shoes was quite good on the model but was judged to be poor in terms of its durability. An assessment of the price is considered quite expensive, this can be due to tiered prices, consumer purchasing decisions on Golfer shoes products are considered less fast and customers are less satisfied with their products. Product quality has a positive and significant impact on purchasing decisions and their implications for customer satisfaction. Prices have a positive and significant effect on purchasing decisions and their implications for customer satisfaction. Simultaneously, product quality and price influence purchasing decisions. Purchasing decisions affect customer satisfaction. The direct influence of product quality on customer satisfaction and the direct effect of prices on customer satisfaction
\end{abstract}

Keywords: Product Quality, Price, Purchase Decision, Customer Satisfaction

\section{Introduction}

Cultural elements are likely to influence buying behaviourof shoes? There are many different aspects of culture that have been analysed by cultural researchers over the years. These related tothe customer segment include, in particular such as youth orientation, long-term vs short-term orientation (also known as time orientation), masculinity vs. femininity, the power distance index, individualism/collectivism, indulgence against restraint and uncertainty avoidance.The need for clothing for each individual is an opportunity for the industry, not only clothes, shoes have become a necessity for society today. With a large population of Indonesia, it is one of the opportunities for business actors in the footwear industry, especially for these shoe products. This potential can be seen from the demographic factors of Indonesia's population. The Director General of Small, Medium and Miscellaneous Industry (IKMA) of the Ministry of Industry, Gati Wibawaningsih, (2018) that the shoe or footwear industry in Indonesia recorded a total production of up to 1.41 billion pairs of shoes. This amount contributes 4.6 percent to the world's total shoe production (Source: https://bisnis.tempo.co/, 2020) Indonesia has 
a strategic position in the production of footwear in the world. The Cibaduyut home shoe industry area has around 250 stalls, which is already known as one of the shopping attractions, from shoes, wallets, to Cibaduyut product bags.

Many shoes produced by Cibaduyut are no less quality than branded shoes from abroad. This is evident from the large number of foreign tourists who visit and shop in Cibaduyut (source: AyoBandung.com, 2020). Tourists

who visit and shop in Cibaduyut (source: AyoBandung.com, 2020).
One of the shoe brands in Cibaduyut is the Golfer brand, which makes shoe products including adult shoes, both women's and men's shoes.

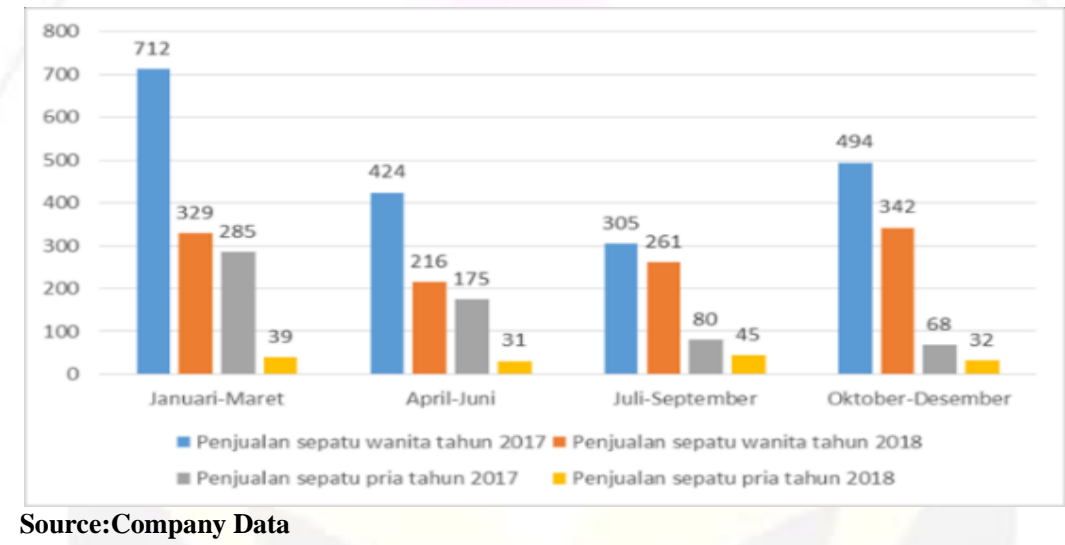

Figure 1.1. Shoe Sales Data (2017 - 2018)

From the data in Figure 1.1, the sales data above shows that sales of women's shoes are more dominant than men's shoes, and sales tend to decline.

Here it can be seen that sales of women's shoes in 2017 in January-March are still 712, then in April-June, July-September there is a decrease, while in October-December there is an increase again, which may be due to an improvement in product quality, and For products that have been lowered for a while, resulting in an increase in consumer purchases, in addition to that, there is also an increase due to sales from buyers of an arisan group, usually at the beginning of the year and the end of the year. then in 2018 in January-March, April-June there was a decline again, then in July-September there was an increase again, this is usually due to the publication of a new model catalog.Whereas the sales of men's shoes in
2017 January-March were at 285, then in April-June, July-September, OctoberDecember continued to decline, in 2018 it fell even further, in January-March, AprilJune there was an increase a little in JulySeptember, but there was a decline again in October-December.

Consumers will prefer products that offer the most quality, high-achieving, or innovative features. Satisfaction also depends on the quality of products and services. Furthermore, Quality (quality) is said to be satisfactory seen from the total feature capabilities and characteristics of these products and services. (Kotler, Philip Keller, 2008)

The increasing number of competitors in the Cibaduyut environment, and in other areas, with an online sales system, this condition provides many choices for consumers, so that 
purchasing decisions become faster with product variations, product quality offered by competitors. Besides product quality, consumers will also take into account the price. At a high level of competition, producers will press prices to make them more competitive.

For consumers, in retail sales, there is a segment of buyers who are very sensitive to the price factor, where price is the only consideration in buying a product, and some are not. The majority of consumers are somewhat price sensitive, but also consider other factors, such as brand image, store location, service, value, product features, and product quality. In addition, consumer perceptions of product quality are often influenced by price. In some cases, high prices are seen as reflecting high quality. according to (Tjiptono, Fandy. Chandra, 2017)

Golfer products, seen from preliminary research, have advantages in the design / shape and beauty of their products, but in terms of product durability are less than optimal and prices have not provided a level of satisfaction to consumers / customers, so it is suspected that the level of purchasing decisions has decreased and satisfaction with products decreased. Sales system for golfer through Offline, Online and Reseller sales systems using the Catalog. For offline sales, customers (members) use a white price list, while for non-member buyers, tourists use a red price list. For online sales, prices in white are used, not including shipping costs. For sales through resellers, in the catalog the price is listed using a green price list, but if the price is not listed in the catalog, a blue, yellow or green price list can be used, depending on the reseller and not including shipping costs.

In addition, there is also a sales system with an arisan system to a certain group and usually the enthusiasts at the beginning of the year and at the end of the year, and this is what causes sales to increase. Price survey to several shops in the vicinity, for the same model and material, there is a cheaper price, probably because the operational costs are not too big

\section{Method}

The method used in this research is descriptive and verification methods. Descriptive method is a research that aims to obtain a description of the strategy to increase customer satisfaction for shoes in Bandung on Golfer shoes in Cibaduyut, Bandung.

Whereas with verification research, basically the researcher wants to test the truth of the hypothesis through data collection in the field, where the research will test the quality of the product through the dimensions of performance, features, reliability, conformance, durability, service ability and test prices through indicators of price affordability, price compatibility with quality, price compatibility with benefits, price competitiveness, purchasing decisions and its implications for customer satisfaction in golfer shoes products in Cibaduyut, Bandung city.

This research method measures research variables, by measuring the dimensions of research variables through statistical measurement techniques through path analysis using a quantitative approach, because the data obtained through the research instrument in the form of a questionnaire.

In data processing, this research uses ordinal data which is converted to interval data for statistical data processing. The data were obtained by adding up the scores on each indicator, which were processed using statistical Software programs, namely

SPSS, Microsoft Excel, and the Successive Interval Method (MSI) program.

\section{Result and Discussion}

\section{Overview of Respondents}

Based on the results of research on the effect of shoe quality and price on purchasing decisions and their implications for customer satisfaction at the Golfer shoe factory in Cibaduyut, Bandung, the data and information obtained are described below. 
This section will explain the results of the research that has been carried out and processed to determine the effect of shoe quality and price on purchasing decisions and their implications for customer satisfaction at the Golfer shoe factory in Cibaduyut, Bandung. The author distributed questionnaires to 1,271 adult shoe customers for both women's and men's shoes, so that after counting the number of respondents it became 93 people.

The profiles of respondents who are asked on the questionnaire are gender, age and length of work. The following is the data that the author obtained regarding the respondent's profile. The authors of this study collected data by several methods, including one by distributing questionnaires to respondents. The following describes the grouping of respondents:

Table 3.1. Distribution of Respondents by Gender

\begin{tabular}{cc|c}
\hline Gender & Amount & Percentage \\
\hline Male & 21 & 22,58 \\
Female & 72 & 77,42 \\
Total & $\mathbf{9 3}$ & $\mathbf{1 0 0 \%}$ \\
\hline
\end{tabular}

Source: questionnaire processing results

From table 3.1 above shows that most of the respondents were female with a total of 72 people or $77.42 \%$, while the rest were male by 21 people or $22.58 \%$

Table 3.2. Distribution of Respondents by Age

\begin{tabular}{cc|c}
\hline Last education & Total & Percentage \\
\hline SD & 5 & 5,38 \\
SLTP & 11 & 11,83 \\
SLA & 17 & 18,28 \\
Diploma & 29 & 31,18 \\
S1 & 22 & 23,66 \\
S2/S3 & 9 & 9,68 \\
\hline Total & $\mathbf{9 3}$ & $\mathbf{1 0 0 \%}$ \\
\hline
\end{tabular}

Source: Research Data, 2019

From table 3.2 above, it can be seen that the majority of respondents are in the age range $31-40$ years as many as 49 respondents or $52.69 \%$, in 11 respondents or $11.83 \%$ in the age range 21-30 years old. Age range $41-50$ years 32 respondents or $34.41 \%$ and $>50$ years of 1 respondent or $1.08 \%$, most of the visitors to the Golfer shoe factory in Cibaduyut, Bandung City are between 31 - 40 years old.

Table 3.3. Distribution of Respondents by Latest Education

\begin{tabular}{cc|c}
\hline Age & $\begin{array}{c}\text { Tota } \\
1\end{array}$ & Percentage \\
\hline $21-30$ Years & 11 & 11,83 \\
$31-40$ Years & 49 & $\mathbf{5 2 , 6 9}$ \\
$41-50$ Years & 32 & 34,41 \\
$>50$ Years & 1 & 1,08 \\
\hline Total & $\mathbf{9 3}$ & $\mathbf{1 0 0 \%}$ \\
\hline
\end{tabular}

Source: questionnaire processing results

From table 3.3 above, the writer can explain that most of the respondents who have had the latest Diploma education are 29 people or $31.18 \%$, SD is as many as 5 people or $5.38 \%$, SLTP is 11 people or $11.83 \%$, SLA is 17 people or $18.28 \%$, has the latest $\mathrm{S} 1$ education as many as 22 people or $23.66 \%$ and the last education S2 / S3 was 9 respondents or $9.68 \%$. From the information above, it can be concluded that most of the visitors to the Golfer shoe factory in Cibaduyut, Bandung, who became respondents had Diploma education.

Table 3.4. Distribution of Respondents by Occupation

\begin{tabular}{cl|c}
\hline Employment & Total & Percentage \\
\hline bureaucrat & 21 & $\mathbf{2 2 , 5 8}$ \\
BUMN / BUMD & 9 & 9,68 \\
Private employees & 11 & 11,83 \\
entrepreneur & 12 & 12,90 \\
Student & 7 & 7,53 \\
Retired & 10 & 10,75 \\
Farmer & 12 & 12,90 \\
Construction workers & 11 & 11,83 \\
\hline Total & $\mathbf{9 3}$ & $\mathbf{1 0 0 \%}$ \\
\hline Source: questionnaire procesing results
\end{tabular}

Source: questionnaire processing results

From table 3.4 above, the author can explain that visitors to the Golfer shoe factory in Cibaduyut, Bandung City who are respondents mostly have jobs as civil servants, namely as many as 21 people or $22.58 \%$ 
Table 3.5. Distribution of Respondents Based on Income Per Month

\begin{tabular}{cc|c}
\hline Employment & Total & Percentage \\
\hline < Rp. 1.500.000 & 15 & 16,13 \\
Rp. 1.500.000-Rp. & 28 & 30,11 \\
3.000 .000 & & \\
Rp. 3.000.000- Rp. & 37 & 39,78 \\
5.000 .000 & & \\
> Rp. 5.000.000 & 13 & 13,98 \\
\hline Total & $\mathbf{9 3}$ & $\mathbf{1 0 0 \%}$ \\
\hline Source: questionnaire processing results
\end{tabular}

Source: questionnaire processing results

From table 3.5 above, the writer can explain that visitors to the Golfer shoe factory in Cibaduyut, Bandung, who are respondents, mostly have monthly income of Rp. 3,000,000 - Rp. 5,000,000, namely 37 people or $39.78 \%$.

Through the statements given by the author in the questionnaire distributed for the purposes of this study, it can be seen that respondents' responses to shoe quality, price, professional skepticism and customer satisfaction at the Golfer shoe factory in Cibaduyut, Bandung City. The 35 statements submitted aim to find out how respondents respond to the influence of shoe quality and price on customer satisfaction at the Golfer shoe factory in Cibaduyut, Bandung, with purchasing decisions as an intervening variable.

\section{Data Quality Test}

To determine whether or not there is a relationship between shoe quality and price on purchasing decisions and its implications for customer satisfaction at the Golfer shoe factory in Cibaduyut, Bandung, the authors use several tests. Because the respondent's answer has an ordinal scale, this answer is calculated based on the results of a distributed questionnaire which consists of 12 statements related to shoe quality, 6 statements related to price, 4 statements related to purchasing decisions and 4 statements related to customer satisfaction.

\section{Types of Data and Data Sources Type of Data}

Data according to its type is divided into two, namely qualitative data and quantitative data. (Abdulrahman, 2018) Qualitative data is a type of data related to categories, characteristics, where the questions are in the form of sentences, usually the data is obtained from interviews, and is subjective in nature because data can be interpreted differently by others, qualitative data can be made into numbers in ordinal or ranking forms, meanwhile What is meant by quantitative data, is data in the form of numbers or presented in the form of numbers obtained either from direct measurement, or numbers obtained by converting qualitative data into quantitative data, and quantitative data is objective in nature and can be interpreted the same by everyone.

In this research, data were obtained from questionnaires of golfer shoe customer respondents as a research instrument, which was distributed to respondents with golfer shoes customers with closed questions, so that the respondent chose from one of the available answers from each question. According to the type of data in this study, including quantitative data, where data is obtained either directly from sales data or from questionnaires, where the results of the questionnaire are converted from qualitative data to quantitative data. Documentation in this study looks at documents to complement research information, including sales data.

\section{Data source}

Data source is anything that can provide information about data. Based on the source data can be divided into two, namely primary data and secondary data. (Abdulrahman, 2018)

1. Primary data is data that is made by the researcher to solve the problem that is being handled by collecting directly from the first source or the place where the research object was carried out. The primary data sources in this study were obtained using a questionnaire distributed to Golfer shoes customers, as well as interviews with Golfer owners and staff.

2. Secondary data is data that is directly collected by researchers as a support, from the first source. Secondary data sources, in research here include journal literature, articles, and internet sites relating to the research conducted, such as the development of the shoe industry. Meanwhile, secondary data sources 
obtained from the object of research, namely from companies, include: shoe sales data, shoe models, price lists.

For this reason, in this study, in addition to primary data obtained from questionnaires distributed to Golfer shoe customer respondents with data related to customer satisfaction dimensions, secondary data sources were also obtained from various sources, including: journal literature, articles, and internet site with regard to the research being carried out.

\section{Research population and sample}

The sampling technique or sampling technique used is Simple Random Sampling, which is "a method of taking samples from members of the population at random without paying attention to the strata (levels) in the members of the population." (Riduwan \& Kuncoro, 2017) This is done when members of the population considered homogeneous (kind). With this sampling technique, every member of the population has an equal chance of being selected as a member of the sample.

In determining the population and sample that will be used as the source of research data, it must be representative. Respondents are Golfer adult shoe customers, who come from the Bandung and Bogor areas, Customers in 2017-2018 who have determined the exact number will be used as the population and research sample

\section{Research Population}

Population is a generalization area consisting of objects or subjects that have certain qualities and characteristics that are determined by the researcher to be studied and then draw conclusions or a set of individual data that has the characteristics applied by the researcher. (A.Gima Sugiama 2008, in Abdulrahman, 2018)

From the above opinion, it can be said that the population is an object or subject in an area or a collection of individual data that has and meets certain requirements related to research problems. The population as the data of this study were customers of adult shoes

Golfer products, both for men's and women's adult shoes. The population data were 1,271 respondents who were customers of adult shoes for both women's and men's shoes, and then how many were the samples in this study.

\section{Research Samples}

Samples are part of the number and characteristics they have by population. (Sugiyono, 2018). By examining the sample, it is expected that the results obtained will provide conclusions and descriptions that are in accordance with the characteristics of the population, so that the results of the conclusions from the sample study can be generalized to the population. The method in determining the number of research samples uses the Slovin formula (Riduan, 2007, in Rohmawati, 2018), with the following formula:

$\mathrm{n}=$ Sample size

$$
n=\frac{N}{N \cdot d^{2}+1}
$$

$\mathrm{N}=$ Population Size

$\mathrm{d}=$ Percentage of leeway due to inaccuracy due to sampling problems which can still be tolerated by $10 \%$ or 0.1

$1=$ Constant value

So that from the population in the study with the Slovin formula, the sample size can be calculated, as follows:

$$
n=\frac{1.271}{1.271\left(0,1^{2}\right)+1}
$$

Based on the Slovin formula from the number of the study population, the data sample can represent a minimum of 93 respondents who can represent the total population.

\section{Variables and Operationalization of Research Variables}

Research variable is an attribute, or nature, or value of people, objects or activities that have certain variations that are determined by the researcher to be studied and then draw conclusions. (Sugiyono, 2018) According to the relationship between one variable and another, the various variables in this study can include:

a. Independent variables, or exogenous variables, are often called independent variables, which are variables that affect 
or cause changes or the emergence of the dependent variable (dependent).

b. Intervening variables are variables that affect the relationship between the independent and dependent variables into an indirect relationship, or intervening variables / between the independent variable and the dependent variable.

c. Dependent variables, or endogenous variables, are often called dependent variables, which are variables that are influenced or become the result, because of the independent variables.

In this study, which becomes the Independent / exogenous variable is Product Quality operated as (X1) and Price operated as (X2), with the Purchasing Decision Intervening variable operated as (Y), and the Dependent / endogenous variable Consumer Satisfaction operated as (Z).

Data Collection Techniques and Data Processing

\section{Data collection technique}

To obtain supporting data in this study, the researcher collected data by means of a survey by distributing questionnaires or questionnaires. "The questionnaire is a data collection technique which is done by giving a set of written questions to the respondent to answer" (Sugiyono 2013, in Alfiani, 2018). The questionnaire is an efficient data collection technique if the researcher knows exactly what variables to measure. The list of questionnaire questions used is closed, meaning that alternative answers have been provided.

\section{Data Processing Methods}

Data processing is done manually and electronically using calculators and computers. Data processing can be done to test the hypotheses that have been formulated. Hypotheses will be tested in relation to the problems outlined in Chapter 1.The steps in data processing in the research carried out are as follows:

1. Editing. Is to correct data which includes completeness of filling or unclear answers. Editing is carried out in the field so that if there is an error or lack of data it can be corrected immediately.

2. Scoring. Give the scoring weight to the questionnaire results
3. Coding. Giving numeric codes (numbers) to data that consists of several categories to make it easier for further data processing.

4. Tabulating. Namely the process of calculating data from a coded respondent questionnaire, then entering it into the table.

5. Data Entry. Is an activity of entering data that has been collected into a master table or computer data base, then making a simple frequency distribution.

6. The data are measured using a Likert scale

"The Likert scale is used to measure the attitudes, opinions and perceptions of a person or group of people towards certain phenomena" according to (Sugiyono, 2018).

The scale measurement has 5 alternative answers explained based on Table 3.1 as follows:

Table 3.6. Likert scale

\begin{tabular}{c|l|c|c}
\hline No. & \multicolumn{1}{|c|}{ Statement } & $\begin{array}{c}\text { Skor } \\
(+)\end{array}$ & $\begin{array}{c}\text { Skor } \\
(-)\end{array}$ \\
\hline 1 & $\begin{array}{l}\text { Very Good } \\
\text { Very Expensive } \\
\text { Very Fast } \\
\text { Very Satisfied }\end{array}$ & 5 & 1 \\
\hline 2 & $\begin{array}{l}\text { Good } \\
\text { Expensive } \\
\text { Fast } \\
\text { Satisfied }\end{array}$ & 4 & 2 \\
\hline 3 & $\begin{array}{l}\text { Pretty good } \\
\text { Quite expensive } \\
\text { Fast enough } \\
\text { Quite satisfied }\end{array}$ & 3 & 3 \\
\hline 4 & $\begin{array}{l}\text { Not good } \\
\text { Not expensive } \\
\text { Not fast } \\
\text { Less satisfied }\end{array}$ & 2 & 4 \\
\hline 5 & $\begin{array}{l}\text { Not very good } \\
\text { Very Not Expensive } \\
\text { Very Not Fast } \\
\text { Very Dissatisfied }\end{array}$ & 1 & 5 \\
\hline & & & \\
\hline
\end{tabular}

Source: Research Data, 2019

\section{Sucsesive Interval Method (MSI)}

The Sucsesive Interval method is used to convert ordinal data to Interval data because the measurements in this study use statistical measurements by using excel.

\section{Research Instrument Testing}

"The research instrument must be of a quality standardized in accordance with the criteria for testing techniques for validity and reliability, with the aim of the research instrument used to have a reliable level of 
reliability that can be accounted for" (Alma 2010, in Yusnaini, 2017)

The data quality test in this study was conducted to determine the level of validity, the value of the correlation coefficient and the level of reliability of the instruments used. As for the calculations using the excel program and SPSS as statistical tools.

The measuring instrument used to test or measure the questionnaire instrument is made by testing as follows:

\section{Validity test}

Validity test to measure the level of reliability, validity, or validity of a research data, by comparing the t-value with the ttable. With the provision that if $\mathrm{t}$ count $>\mathrm{t}$ table it is said to be valid and if $\mathrm{t}$ count $<\mathrm{t}-$ table it is said to be invalid". (Sugiyono 2017, in Yusnaini, 2017)

For that by comparing if the t-count is greater than the t-table, then the data can be said to be valid, whereas if the t-count is smaller than the $\mathrm{t}$-table, then the data is said to be invalid.

Before the questionnaire is used for actual data collection,

First, a trial was conducted on respondents who had the same characteristics as the characteristics of the study population. The trial was conducted to determine the level of validity (validity) and consistency (reliability) of research measuring instruments, in order to obtain questions that were appropriate to be used as a measuring tool for research data collection.

"A valid instrument means the measuring instrument used to obtain data (measure) is valid. Valid means that the instrument can be used to measure what should be measured "(Sugiyono 2016, in Abdulrahman, 2018).

Validity testing is done by calculating the correlation between each statement and the total score. The formula for the Pearson correlation is as follows:

$r=\frac{\sum x y-\frac{\left(\sum x\right)-\left(\sum y\right)}{N}}{\sqrt{\left(\sum x^{2}-\frac{\sum x^{2}}{N}\right)\left(\sum y^{2}-\frac{\sum y^{2}}{N}\right)}}$
Information :

$\mathrm{r}=$ Pearson correlation coefficient $\mathrm{X}=$ score of the question item

$\mathrm{Y}=$ total score of question items

$\mathrm{N}=$ Number of respondents in the implementation of the instrument trial

If $r$ is greater or equal to $0.30(r \geq 0.30)$ then the item is declared valid. This means that the research instrument has a degree of accuracy in measuring research variables, and is suitable for use in testing research hypotheses. If $\mathrm{r}$ is less than $0.30(\mathrm{r}<0.30)$, then the item is declared invalid, and will not be included in testing its typhoid or the instrument is excluded from the variable measurement. Testing the validity in this study can be done using the SPSS program, by examining the Pearson correlation values. After finding the statements (items) used in this study are valid, then the statements declared valid are tested for reliability.

\section{Reliability Test}

Reliability testing aims to determine the reliability of the measuring instruments used. This reliability shows the accuracy and homogeneity of the questionnaire used as a measuring tool. Reliability refers to the degree of consistency and stability of the data or findings. "Reliability refers to the level of reliability of something, meaning that it can be trusted then it can be relied on" (Arikunto, 2013, in Abdulrahman, 2018). Reliable instruments can produce reliable data. The reliability calculation technique used in this study is the Cronbach's Alpha test (Husein Umar, 2008, in Abdulrahman, 2018) with the formula:

Information :

$r=\left[\frac{k}{(k-1)}\right]\left[1-\frac{\sum \sigma_{h}^{2}}{\sigma_{1}^{2}}\right]$

$\mathrm{r}=$ Reliability coefficient sought

$\mathrm{k}=$ Number of statement items (number of statements)

$\sum \sigma_{h}^{2}=$ Total variance of statement items

$\sigma_{1}^{2}=$ Test score variance (total variance)

The scale reliability coefficient should be as high as possible, that is magnitude close to one. The decision rule uses the alpha cronbrach critical value, namely if the 
coefficient value is $\geq 0.60$ then the instrument is declared reliable and can be used for research.

To get the Cronbach alpha value in this study, a statistical tool was used with the SPSS computer program after meeting the data validity value.

The reliability level criteria can be seen as follows:

Table.3.7. Reliability level provisions

\begin{tabular}{cl}
\hline $\begin{array}{l}\text { Cronbach } \\
\text { Alpha }\end{array}$ & $\begin{array}{l}\text { Reliabili } \\
\text { ty Level }\end{array}$ \\
\hline$\leq \mathbf{0 , 5}$ & Low \\
\hline $\mathbf{0 , 6}$ & $\begin{array}{l}\text { Accepta } \\
\text { ble }\end{array}$ \\
\hline$\geq 0,7$ & Enough \\
\hline$\geq 0,8$ & High \\
\hline$\geq 0.9$ & Perfect \\
\hline
\end{tabular}

Setiaji (2004 in Yusnaini, 2017)

1. If Cronbach alpha $=$ or $<$ than 0.5 , it means that the research instrument has a low level of reliability.

2. If Cronbach alpha $=$ or $>0.6$ then the research instrument has an acceptable level of reliability

3. If Cronbach alpha $=$ or $>0.7$, it means that the level of reliability is sufficient

4. With Cronbach alpha $=$ or $>0.8$, this indicates high reliability

5. Meanwhile, if Cronbach neglected $=$ or $>$ 0.9 , then the reliability is perfect.

\section{Normality test}

"The normality test aims to test whether in the regression model confounding or residual variables have a normal distribution". (Ghozali 2011, in Abdulrahman, 2018) In other words, the normality test is carried out to determine the nature of the distribution of research data which serves to determine whether the sample taken is normal or not by testing the distribution of the analyzed data. There are several ways that can be used to see normality in this study, namely by using 3 test tools, namely:

1. Kolmogrov Smirnov test, in this test the guidelines used in decision making, namely, by comparing the results of the Komolgrov Smirnov count with the Kolmogrov Smirnov table, using the processed SPSS results, conclusions can be drawn by looking at Sig (2-tailed), if Sig ( 2-tailed) is greater than the level of significance used, it can be concluded that the analyzed residuals are normally distributed.

The hypothesis used:

Ho: residual data are normally distributed

Ha: residual data are not normally distributed

2. Histogram, which is a test using the provision that normal data is Bell shaped. Good data is data that has a normal distribution pattern. If the data is skewed to the right or to the left, it means that the data is not normally distributed.

3.Normality Probability Plot graph, the terms used are:

a. If the data spreads around the diagonal line and follows the direction of the diagonal line, the regression model fulfills the normality assumption.

b. If the data spreads far from the diagonal or does not follow the direction of the diagonal line, the regression model does not meet the normality assumption.

\section{Conclusion}

1. The quality of the Golfer shoe product is considered quite good with the lowest rating on the reliability statement in terms of its durability, the assessment of the price is considered quite expensive with the highest rating on products which are expensive and the problem in price means that some customers think that the price offered is still expensive. The purchasing decision for Golfer shoes is considered not fast enough so that it still needs to be improved again. The lowest assessment is on the statement when looking at the quality of existing products, then the decision to buy is fast "and" if you look at the current price offered, it means that some customers are not fast enough to buy Golfer shoes. Overall, customers feel quite satisfied as evidenced by the lowest assessment of the majority repurchase statement after buying the product, but to recommend it to others is considered less satisfied. 
2. Product quality has a positive and significant effect on purchasing decisions and its implications for customer satisfaction with t value among 2.500 .

3. an influence positive and significant price on purchasing decisions and its implications for customer satisfaction.

4. positive influence and significant product quality and price on purchasing decisions.

5. a positive and significant effect of purchasing decisions on satisfaction. customer.

6. positive and significant influence between product quality on customer satisfaction.

7. positive and significant effect between price and satisfaction. customer.

\section{References}

Abdulah, Thamrin.Tantri, F. (2012). Manajemen Pemasaran. Jakarta.

Abdulrahman, S. (2018). Pengaruh Kualitas Pelayanan Kesehatan terhadap Kepuasan pasien rawat jalan yang menggunakan BPJS kesehatan di Puskesmas cicangkanggirang kecamatan sindangkerta Kabupaten Bandung Barat. Program Studi Magister Manajemen Program Pascasarjana Universitas Sangga Buana YPKP Bandung.

Alfiani, I. F. (2018). Pengaruh Disain Produk dan Promosi Secara Online pada Citra Merek dan implikasinya terhadap Keputusan Pembelian (Studi kasus pada produk tas Niion di kota Bandung). Program Studi Magister Manajemen Universitas Sangga Buana YPKP Bandung.

Amanah, D. (2010). Pengaruh Harga Dan Kualitas Produk Terhadap Kepuasan Konsumen Pada Majestyk Bakery \& Cake Shop Cabang H.M. Yamin Medan. Jurnal Keuangan \& Bisnis, 2(1), 71-87. https://doi.org/10.17605/OSF.IO/HNGV J

Aristo, S. F. (2016). Pengaruh produk, harga, dan promosi terhadap keputusan pembelian konsumen woles chips. Jurnal Manajemen Dan StartUp Bisnis, 1(4).
Dewi, \& Kristina, M. (2013). Efek moderasi kepuasan konsumen pada pengaruh harga dan kualitas terhadap keputusan pembelian sepeda motor honda.

Jurnal Ekonomi Dan Kewirausahaan, 13(1), $1-13$.

Ghanimata, F. (2012). Analisis pengaruh harga, kualitas produk, dan lokasi terhadap keputusan pembelian.

Hasyasin, Y. N. (2017). Pengaruh kualitas produk dan harga terhadap keputusan pembelian konsumen (Survei pada konsumen yellow truck kafe Bandung).

Jasa Suatma. (2013). Analisis strategi inovasi atribut produk dan pengaruhnya terhadap keputusan pembelian konsumen pada skuter matik merek honda vario di kota Semarang. Jurnal Stie Semarang, 5(2), 19-35.

Kodu, S. (2013). Harga, kualitas produk dan kualitas pelayanan pengaruhnya terhadap keputusan pembelian mobil toyota avanza. Jurnal EMBA, 1(3), 1251-1259.

Koko Arie Bowo, Abdul Hoyyi, M. A. M. (2013). Analisis faktor-faktor yang mempengaruhi keputusan pembelian dan kepuasan konsumen pada notebook merek acer. Jurnal Gaussian, 2(1), 29-38.

Kotler, Philip.Keller, K. (2008). Manajemen Pemasaran (13th ed.). Jakarta: Erlangga.

Limakrisna, N. P. T. P. (2017). Manajemen Pemasaran (2nd ed.). Jakarta: Mitra Wacana Media.

Maghfiroh, K. (2019). Pengaruh harga, kualitas produk dan word of mouth terhadap kepuasan konsumen serta implikasinya pada keputusan pembelian smartphone xiaomi. Business Management Analysis Journal (BMAJ), 2(2), 34-44. https://doi.org/10.1017/CBO978110741 5324.004 